\title{
Finite Element Modeling and Nonlinear Analysis on the Optimum Opening Location for Continuous Composite Beams with Web Openings
}

\author{
Longqi LI, Wenyuan LIAO*, Bingyong HUO
}

\begin{abstract}
This paper presents a new research perspective for studying the influence of the web opening location on continuous composite beams. Nonlinear finite element models were established to precisely simulate continuous composite beams. The hole location was taken as the variable parameter, and the optimal web opening location of continuous composite beams was comprehensively analyzed and studied from five perspectives. The results show that the most advantageous location is the sagging bending moment region near the side supports. At this location, the composite beam has a relatively higher ultimate bearing capacity and ductility, and the beam is allowed to develop a certain degree of plasticity before shear failure of the opening. In addition, the web opening brings amplitude modulations at two moments to the continuous composite beam.
\end{abstract}

Keywords: continuous composite beam; force distribution; moment amplitude modulation; numerical calculation; web opening

\section{INTRODUCTION}

As a transverse bearing component, composite beams have been increasingly widely utilized in civil and industrial infrastructure. In recent decades, the behavior of providing composite beams with web openings to facilitate pipeline passage has been studied by an increasing number of scholars (Fig. 1).

It is clear that including large web openings has a significant influence on the mechanical properties of composite beams. Therefore, scholars worldwide have carried out much research on this issue.

Clawson and Darwin [1] studied several composite beam specimens with rectangular web openings and proposed that the calculation results will be conservative if the concrete slab's contribution at the opening is not considered. Based on strength criteria, a unified approach was presented by Redwood and Cho [2], Lawson and Chung [3] for designing steel and composite members with web openings. Darwin and Donahey [4] tested fifteen fullscale specimens with web openings and proposed simplified formulas to calculate the bearing capacity of composite beams. Cho and Redwood [5] studied the loadcarrying capacity and force transfer mechanism at the composite beam's web opening.

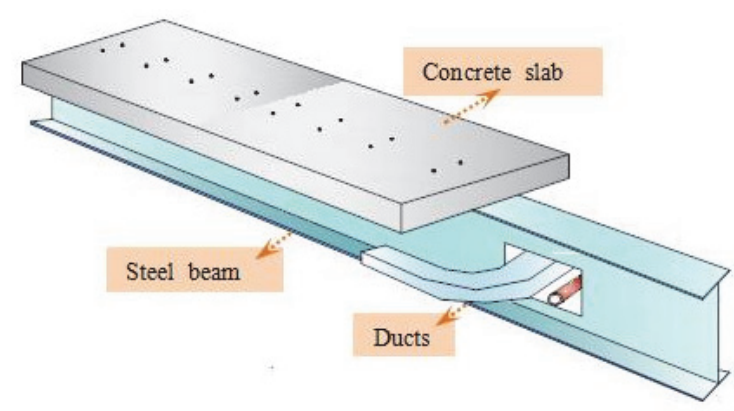

Figure 1 Composite beams with web openings

More recently, Ellobody and Young [6] reported on extensive parametric studies on profiled composite beam specimens with and without stiffened web openings using ABAQUS software. However, the main points of their research mostly focused on the failure mode and loadcarrying capacity of simply supported beams with diverse
$M / V$ (moment-to-shear) ratios at the web opening region. Lim et al. [7] conducted typical pull-out tests on composite beams with web openings, and developed nonlinear 3-D finite element models to investigate the pull-out failure mode, which has been recognized as one of the potential failure patterns by relevant organizations and institutes [8].

In addition, it should be noted that most literature involves research on simply supported steel and composite beams with web openings of different shapes [9-11]. However, for the continuous composite beam with web openings, there is sparse literature $[12,13]$. The continuous composite beam is a statically indeterminate structure, which means that the opening's influence is not only limited to some contents of the simply supported beams mentioned above but also includes aspects such as the plasticity and plasticity development and internal force redistribution. Unfortunately, these aspects have not been reported in more detail. Although experimental studies allow observation and analysis of the mechanical performance of continuous composite beams, they cannot comprehensively and continuously reflect the overall mechanical performance of continuous composite beams, and it is generally time-consuming and uneconomical. To further determine whether the location of web openings influences continuous composite beams, precise finite element models of continuous composite beams were established using an ANSYS package in this study and were validated against the experimental results in reference [13]. In addition to the common research on ultimate bearing capacity and deformation capacity of composite beams with web openings, this study considers the influence of opening locations on the plasticity performance, vertical shear distribution and bending moment redistribution of continuous composite beams. This study lends itself to another interesting problem: how to determine a more advantageous web opening location in continuous composite beams.

\section{SPECIMEN DESIGN}

\subsection{Geometric Parameters of Specimens}

For the convenience of the comparative study, by referring to the specimen parameters in reference [13], four 
continuous beam specimens were designed with different opening locations (labeled TCB1-TCB4, in which specimen TCB3 corresponds to specimen $\mathrm{CCB} 2$ in reference [13]). All specimens had two equal spans. In accordance with the design of the complete shear connection, the welded studs as shear connectors of specimens were arranged in a single row and had diameters of $19 \mathrm{~mm}$ and were spaced at $100 \mathrm{~mm}$. The concrete strength grade of all continuous beam specimens was $\mathrm{C} 30$ [14], and the steel beam was made of Q235B hot-rolled Hbeam. The loading mode was symmetrical centralized loading at two points in the middle span. The basic geometric parameters of continuous beam specimens TCB1 through TCB4 are shown in Fig. 2.

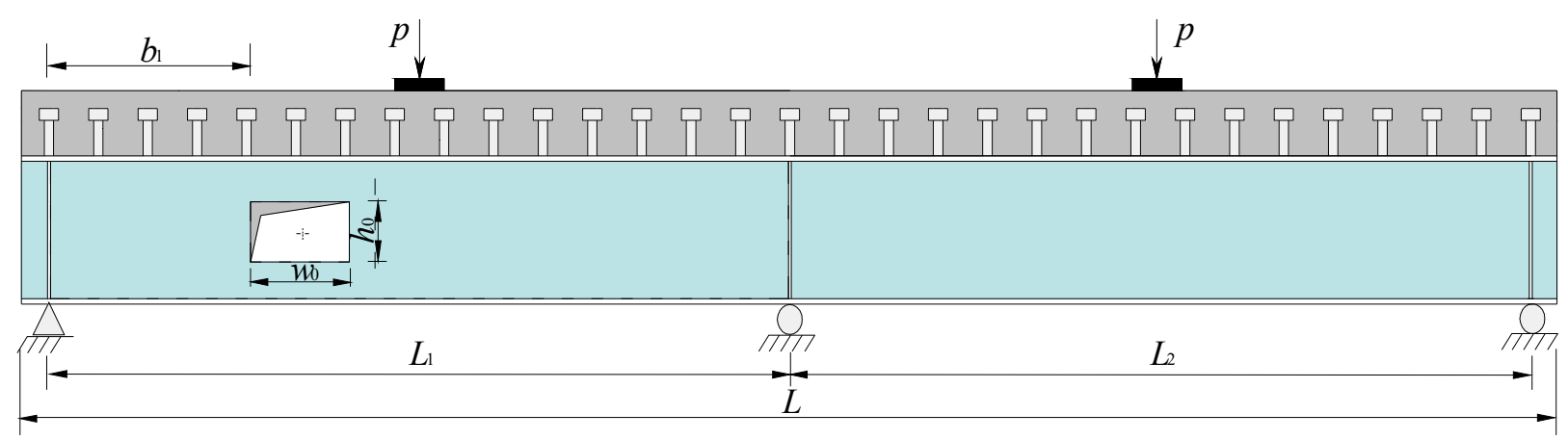

(a) Longitudinal dimensions of the continuous composite beam

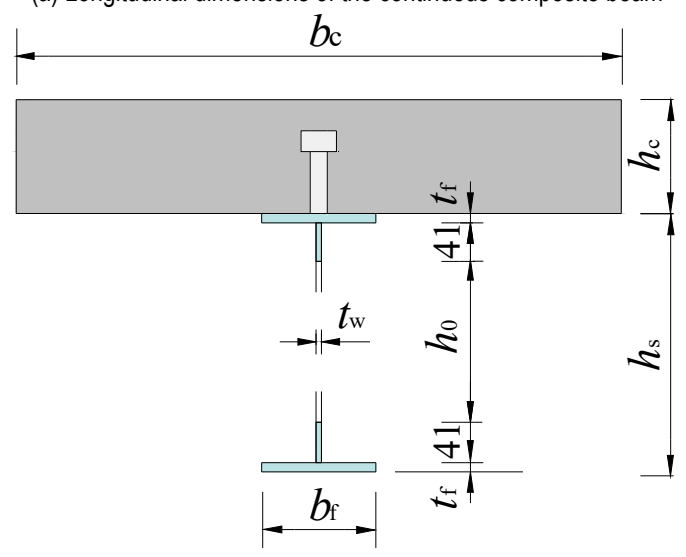

(b) Cross-sectional size

Figure 2 Geometrical dimensions of the continuous composite beam specimens

\subsection{Web Opening Location}

Considering the loading mode symmetry and the beam specimen geometry, the opening location variable can be restricted to varying within the left span of the specimens. In this paper, a total of four different opening locations were designed; the opening location for each specimen is shown in Fig. 3. The opening of TCB1 was located in the sagging moment and positive shear area; the opening of TCB2 was located in the sagging moment and negative shear region; the center line of the TCB3 opening was located at the bending moment reverse bending point, crossing the sagging and hogging bending moment regions; the TCB4 opening was located in the hogging moment region near the middle support of the continuous beam specimen. For more detailed parameters of TCB1 through TCB4, see Tab. 1.

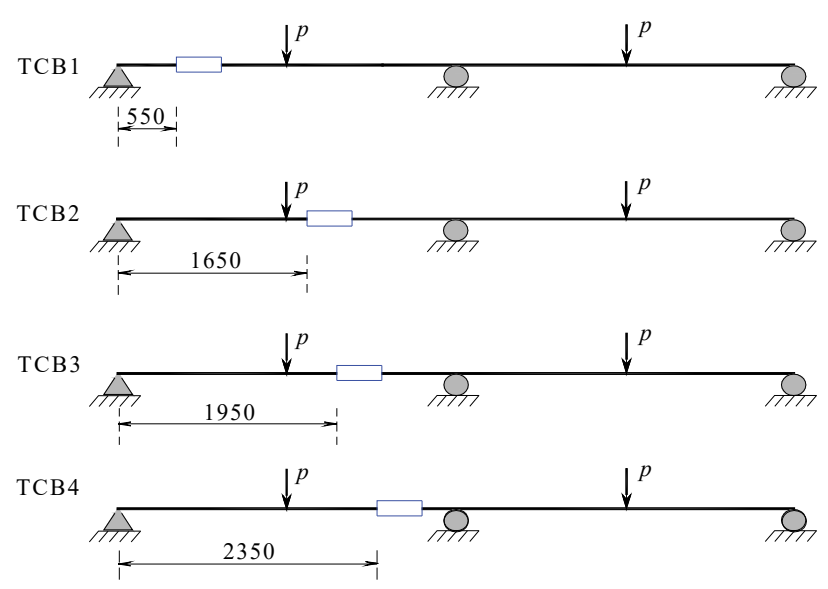

Figure 3 Specimen opening locations

Table 1 Details of continuous composite beam specimens

\begin{tabular}{|c|c|c|c|c|c|c|c|c|}
\hline \multirow{2}{*}{ No. } & Opening size & Steel section & Span length & Opening location & \multicolumn{2}{|c|}{ Concrete slab } & \multicolumn{2}{|c|}{ Reinforcement ratio / \% } \\
\hline & $b_{0} \times h_{0} / \mathrm{mm}$ & $h_{\mathrm{s}} \times b_{\mathrm{f}} \times t_{\mathrm{w}} \times t_{\mathrm{f}} / \mathrm{mm}$ & $L_{1}=L_{2} / \mathrm{mm}$ & $b_{1} / \mathrm{mm}$ & $b_{\mathrm{c}} / \mathrm{mm}$ & $h_{\mathrm{c}} / \mathrm{mm}$ & Longitudinal & Transverse \\
\hline TCB1 & $400 \times 150$ & $250 \times 125 \times 6 \times 9$ & 3000 & 550 & 1000 & 110 & 0.5 & 0.86 \\
\hline TCB2 & $400 \times 150$ & $250 \times 125 \times 6 \times 9$ & 3000 & 1650 & 1000 & 110 & 0.5 & 0.86 \\
\hline TCB3 & $400 \times 150$ & $250 \times 125 \times 6 \times 9$ & 3000 & 1950 & 1000 & 110 & 0.5 & 0.86 \\
\hline TCB4 & $400 \times 150$ & $250 \times 125 \times 6 \times 9$ & 3000 & 2350 & 1000 & 110 & 0.5 & 0.86 \\
\hline
\end{tabular}

$* h_{\mathrm{s}}$ is the height of the steel beam, $b_{\mathrm{f}}$ is the width of the steel flange, $t_{\mathrm{f}}$ is the flange thickness, $t_{\mathrm{w}}$ is the thickness of the steel web, $h_{\mathrm{c}}$ and $b_{\mathrm{c}}$ are the thickness and width of the concrete slab, respectively. 


\section{MATERIAL PARAMETERS AND FINITE ELEMENT MODELING OF SPECIMENS \\ 3.1 Concrete Material Properties}

In the finite element model, the multilinear isotropic strengthening model (MISO) was adopted for the stressstrain relationship of concrete $[14,15]$ shown in Fig. 4 as:

$$
\sigma_{\mathrm{c}}= \begin{cases}f_{\mathrm{c}}\left[1-\left(1-\frac{\varepsilon_{\mathrm{c}}}{\varepsilon_{0}}\right)^{2}\right] & \varepsilon_{\mathrm{c}} \leq \varepsilon_{0} \\ f_{\mathrm{c}}\left[1-0.15\left(\frac{\varepsilon_{\mathrm{c}}-\varepsilon_{0}}{\varepsilon_{\mathrm{cu}}-\varepsilon_{0}}\right)\right] & \varepsilon_{0}<\varepsilon_{\mathrm{c}} \leq \varepsilon_{\mathrm{cu}}\end{cases}
$$

where the stress-strain curves of concrete $\varepsilon_{0}=0.002, \varepsilon_{\mathrm{cu}}=$ 0.0033 , and $f_{\mathrm{c}}$ is the axial compressive strength of concrete.

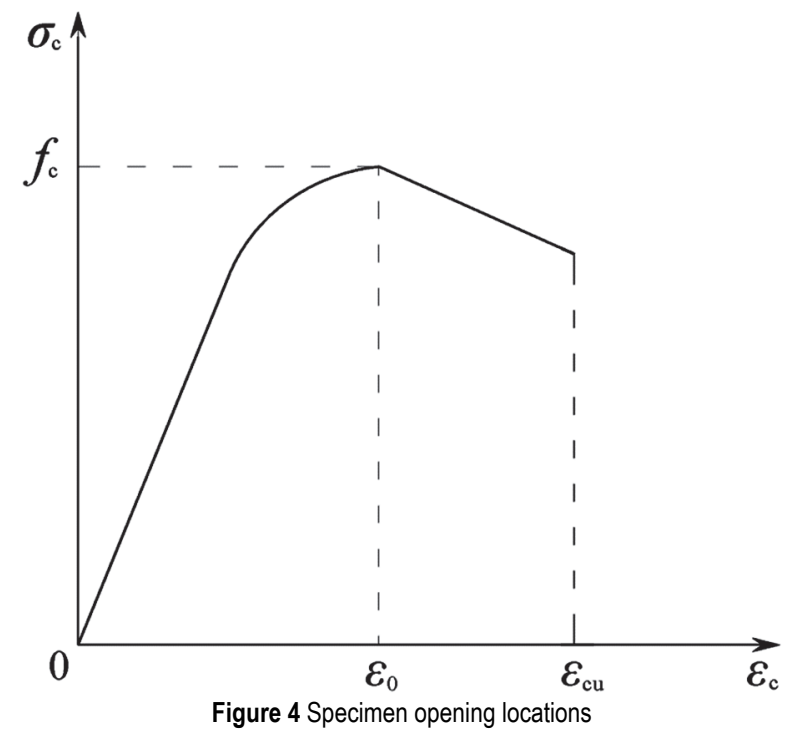

\subsection{Steel Properties}

To assist the nonlinear finite element calculation convergence, the constitutive relationships of the $\mathrm{H}$-section steel and reinforcing bar are modeled by an elastic-plastic model with a strengthening stage.

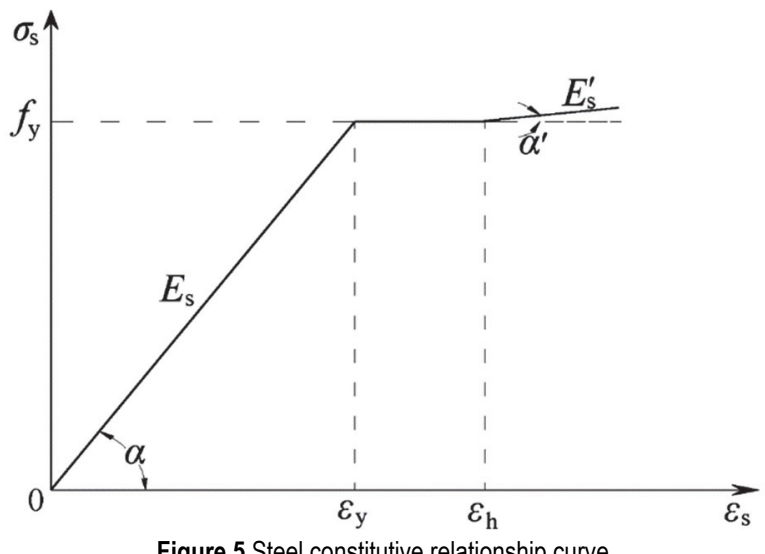

As shown in Fig. 5, the mathematical expressions of stress-strain are as follows:

$$
\sigma_{\mathrm{c}}= \begin{cases}E_{\mathrm{s}} \varepsilon & 0<\varepsilon<\varepsilon_{y} \\ f_{y} & \varepsilon_{y}<\varepsilon<\varepsilon_{\mathrm{h}} \\ f_{y}+E_{\mathrm{s}}^{\prime}\left(\varepsilon-\varepsilon_{\mathrm{h}}\right) & \varepsilon \geq \varepsilon_{\mathrm{h}}\end{cases}
$$

In this study, for the steel, $E_{\mathrm{s}}=2.06 \times 10^{5} \mathrm{MPa}$, and the strengthened modulus of elasticity $E_{\mathrm{s}}^{\prime}=0.01, E_{\mathrm{s}}=2.06 \times 10^{3}$ $\mathrm{MPa}$. The yield strength of steel, $f_{y}$, is based on data from reference [13].

\subsection{Stud Properties}

The load-slip curve given by Ollgaard et al. [16] is used for composite beam shear connectors, as shown in Fig. 6. Compared with the longitudinal slip caused by the longitudinal shear between a composite beam's concrete slab and steel beam, the uplift forces at the interface have less effect on the mechanical behavior of continuous composite beam specimens. Therefore, the uplift forces of the studs can be neglected. In this way, the finite element analysis directly couples the longitudinal and transverse degrees of freedom of the steel and concrete joints at the composite beam interface.

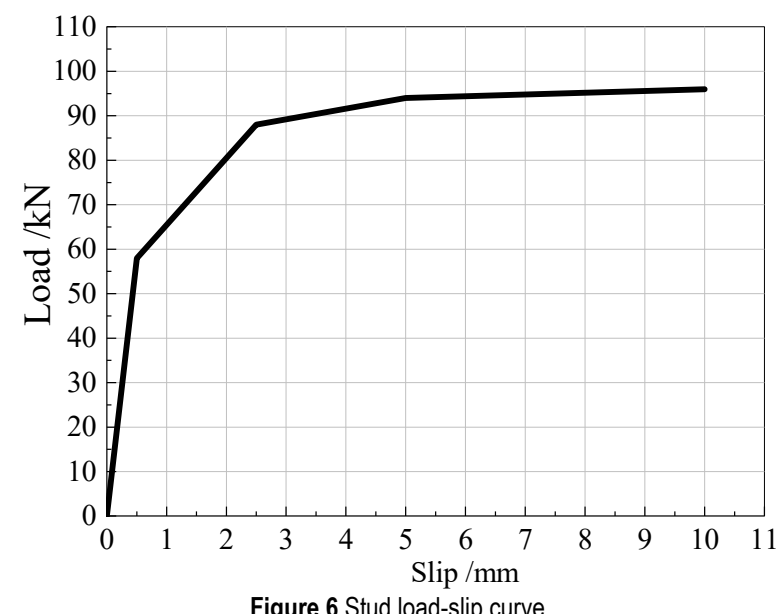

\subsection{Establishing the Finite Element Model}

Finite element models of continuous composite beams were developed using an ANSYS package. In the finite element models, the Solid65 element is employed to simulate the reinforced concrete slabs; the Solid45 element is used to simulate the upper and lower flanges of the steel beams; the Link8 element is used to simulate the steel bars in the concrete; the Shell43 element is used to simulate the steel beam stiffeners; the Plane42 element is adopted to simulate the steel beam web plate, and the welded studs are simulated by the spring element Combin39. To aid calculation convergence, rigid plates were set at the loading point of the composite beam model to transmit the concentrated load evenly, and more refined mesh sizes were chosen at the web opening area; to prevent the web buckling of the steel beams, stiffeners were used at the support and mid-span of the composite beams. Taking TCB2 as an example, the finite element mesh and the general layout of the established model is shown in Fig. 7. 


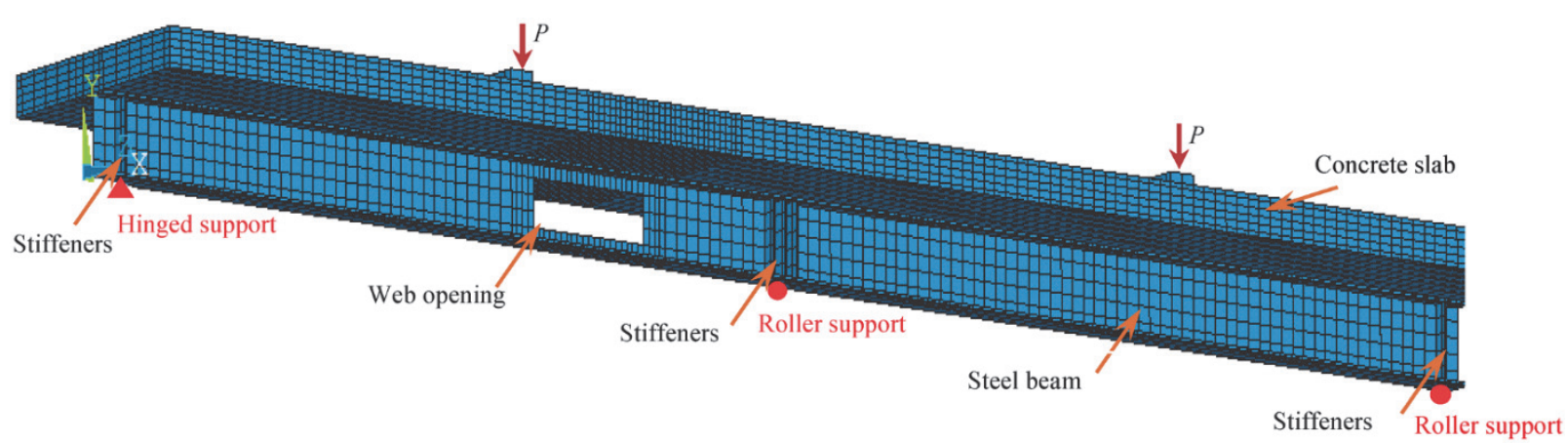

Figure 7 Finite element model of specimen TCB2

\section{ANALYSIS OF FINITE ELEMENT RESULTS \\ 4.1 Strength and Deformation of Specimens}

The load-displacement curves of continuous beam specimens TCB1-TCB4 with different opening locations are also compared in Fig. 8. More detailed data on the ultimate bearing capacity and deformation of the specimens are given in Tab. 2. The following conclusions are drawn, based on the results of Fig. 8 and Tab. 2:

1) TCB1 has better ductility and a higher load-carrying capacity than TCB2, TCB3 and TCB4.

2) The ultimate load-carrying capacity and deformability of the specimens decreases gradually as the opening location moves towards the intermediate support.

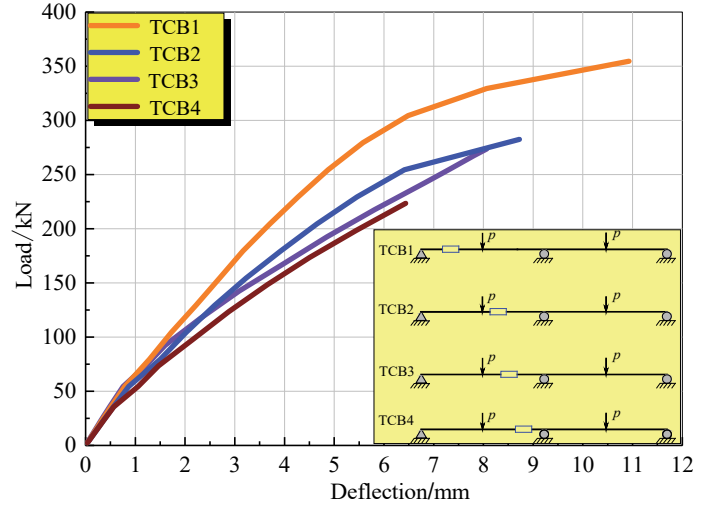

Figure 8 Load-displacement curves of composite beams with varied opening locations

Table 2 Ultimate bearing capacity and deformation of specimens

\begin{tabular}{|c|c|c|c|c|}
\hline \multirow{2}{*}{ No. } & Opening size & Opening location & Ultimate load & Max. deflection \\
\cline { 2 - 5 } & $b_{0} \times h_{0} / \mathrm{mm}$ & $b_{1} / \mathrm{mm}$ & $P_{\mathrm{u}} / \mathrm{kN}$ & $f_{\mathrm{u}} / \mathrm{mm}$ \\
\hline TCB1 & $400 \times 150$ & 550 & 354 & 10.93 \\
\hline TCB2 & $400 \times 150$ & 1650 & 279 & 8.73 \\
\hline TCB3 & $400 \times 150$ & 1950 & 274 & 8.07 \\
\hline TCB4 & $400 \times 150$ & 2350 & 220 & 6.44 \\
\hline
\end{tabular}

\subsection{Cross-Sectional Shear Distribution}

Taking TCB3 (with and without web openings) as an example, Fig. 9 calculates the cross-sectional shear values of the concrete slab and steel beam along the beam length.

\subsubsection{Web without Openings}

1) For beams without web openings, the crosssectional shear force borne by the steel beam is larger than that borne by the concrete slab at any stage of loading, as shown in Fig. 9a. For example, when the load reaches the ultimate capacity (denoted by $1.00 P_{\mathrm{u}}$ ), the concrete slab bears $22.04-31.36 \%$ of the cross-sectional shear force of the entire composite beam, while the steel beam bears $68.64-77.96 \%$ of the total shear force.

2) For the same load step (Fig. 9a), the cross-sectional shear force of the concrete slab and the steel beam both increase, but the former is obviously smaller than the latter.

3) With increasing load, the concrete slab shear force increases, but the fastest rate of increase lies in the $0.75 P_{\mathrm{u}^{-}}$ $1.00 P_{\mathrm{u}}$ load section. Conversely, the rate of increase in the shear force decreases at the steel beam cross section. This indicates that at this stage $\left(0.75 P_{\mathrm{u}}-1.00 P_{\mathrm{u}}\right)$, with the development of composite beam plasticity, the phenomenon of vertical shear redistribution across the composite beam appears.

\subsubsection{Web with Openings}

1) With increasing load (Fig. 9b), the concrete slab at the web opening region bears most of the sectional shear force, while the steel beam bears a small part of the shear force.

2) When the ultimate load is reached, the steel beam bears approximately $11.6 \%$ of the shear force, while the concrete slab bears $88.4 \%$ of the cross-sectional shear force. Therefore, it is worth noting that the vertical shear force at the web opening region may play a controlling role in the design, a factor that is not considered in composite beams without web openings.

\subsubsection{Sectional Shear Force Borne at the Web Opening Region}

1) With increasing load (Fig. 9b), the concrete slab at the web opening region bears most of the sectional shear force, while the steel beam bears a small part of the shear force.

Tab. 3 lists the ultimate shear forces acting on concrete slabs and steel beams at the TCB1-TCB4 specimen web openings. The variation in web opening location has little effect on the cross-sectional shear force borne by the composite beam components. Generally, the shear ratio of the concrete slabs and steel beams at the opening area can reach 9:1 when reaching the ultimate bearing capacity. 


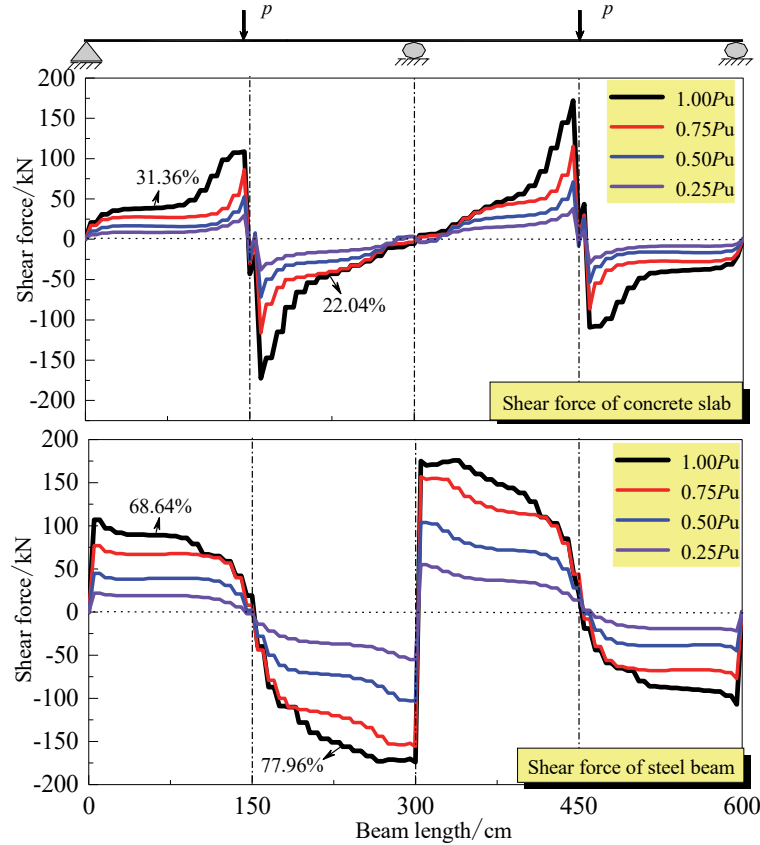

(a) Continuous composite beam without web opening

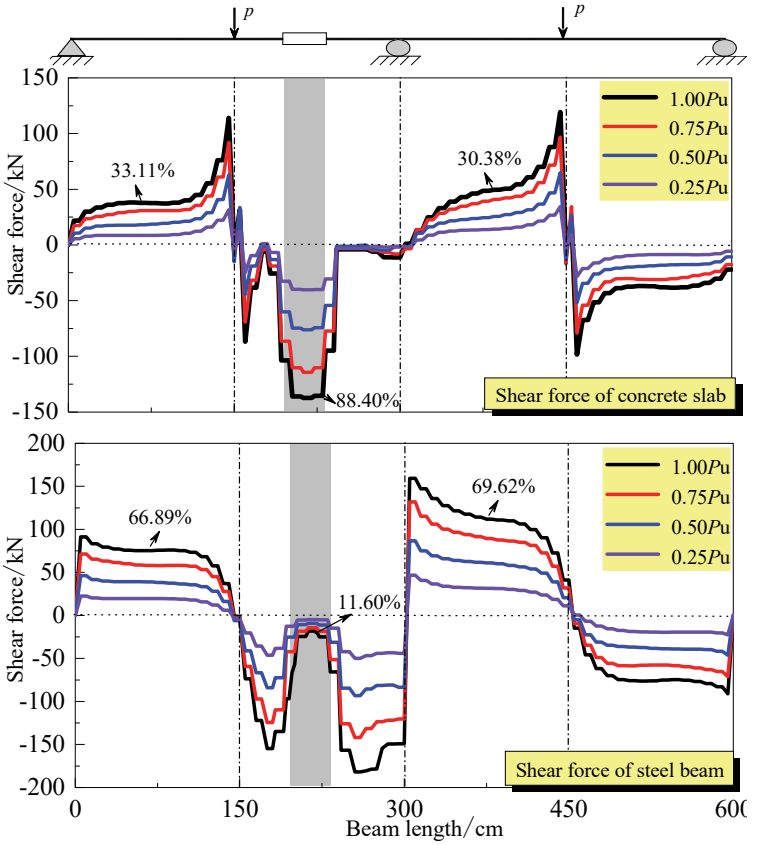

(b) Continuous composite beam with web opening

Figure 9 Shear distribution of steel and concrete slabs along the length of composite beams

Table 3 Ultimate bearing capacity and deformation of specimens

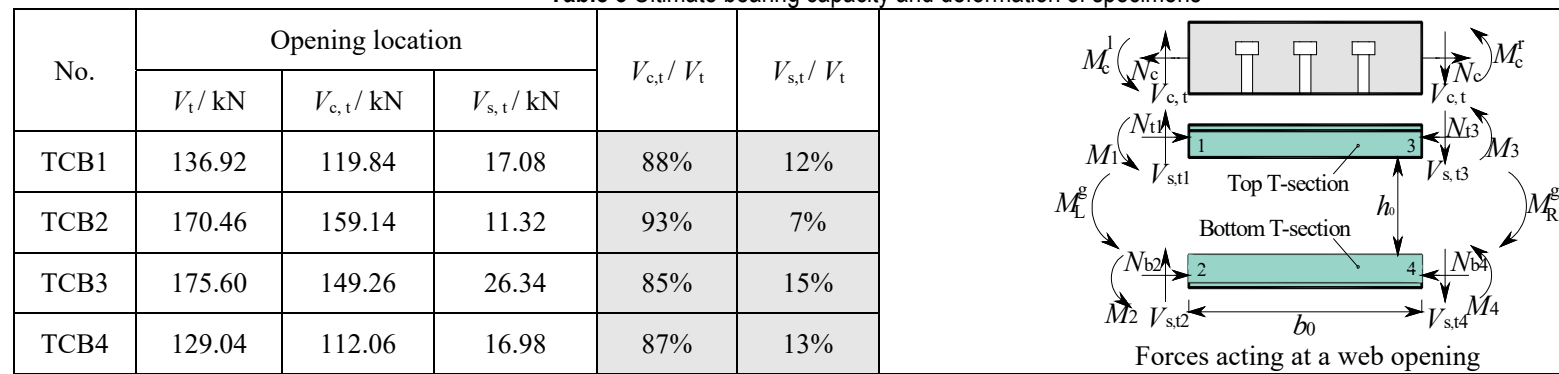

Note: $V_{\mathrm{t}}$ is the total sectional shear force; $V_{\mathrm{c}, \mathrm{t}}$ is the shear force borne by the concrete slabs; $V_{\mathrm{s}, \mathrm{t}}=V_{\mathrm{s}, \mathrm{t} 1}+V_{\mathrm{s}, \mathrm{t}}, V_{\mathrm{s}, \mathrm{t}}$ is the shear force borne by the steel beams, $V_{\mathrm{s}, \mathrm{t}}$ is the shear force in the top T-section of the steel beams, $V_{\mathrm{s}, \mathrm{t} 2}$ is the shear force in the bottom T-section of the steel beams; $M_{\mathrm{L}}{ }^{\mathrm{g}}$ and $M_{\mathrm{R}}{ }^{\mathrm{g}}$ are the total bending moments at the left and the right ends of an opening.

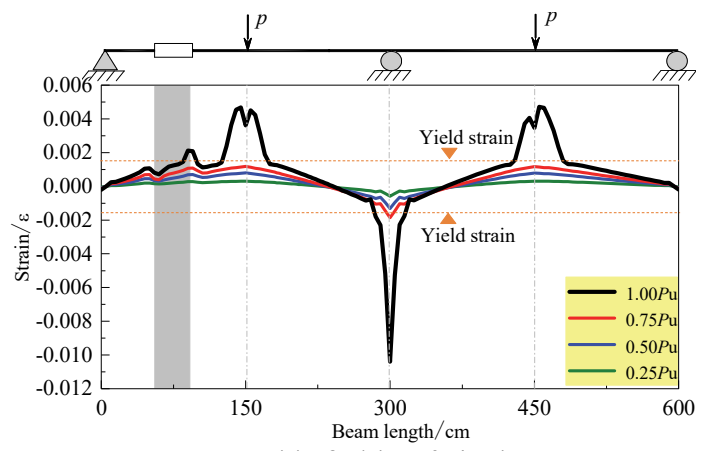

(a) TCB1 $\left(P_{\mathrm{u}}=354 \mathrm{kN}\right)$

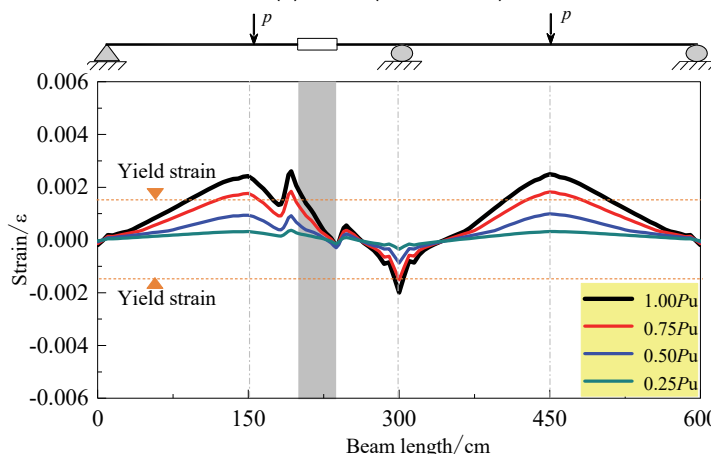

(c) $\operatorname{TCB} 3\left(P_{\mathrm{u}}=274 \mathrm{kN}\right)$

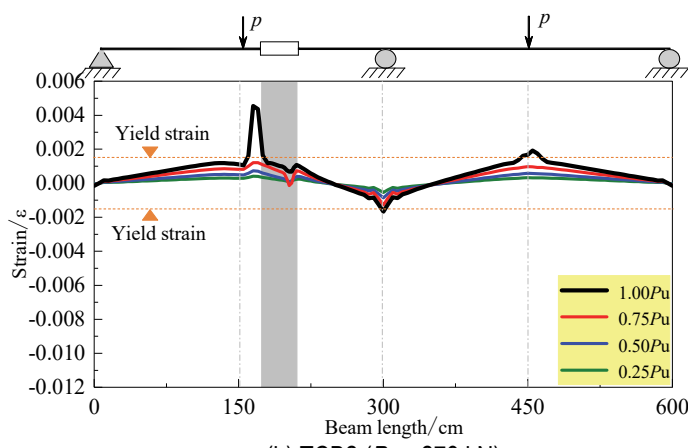

(b) TCB2 $\left(P_{u}=279 \mathrm{kN}\right)$

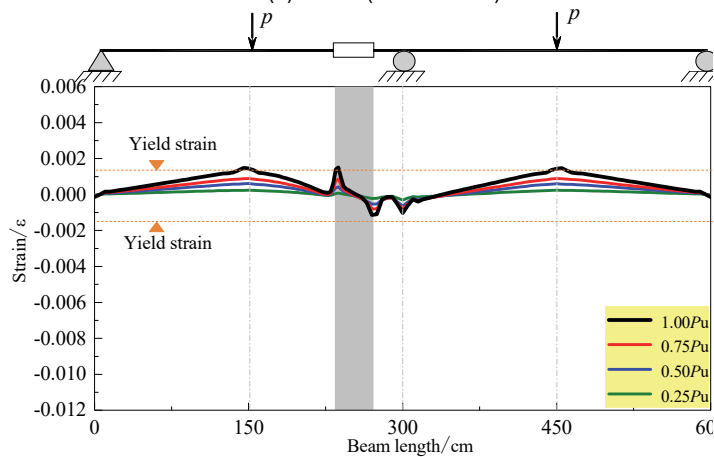

(d) TCB4 $\left(P_{u}=220 \mathrm{kN}\right)$

Figure 10 Longitudinal strain at the bottom of the steel composite beam 


\subsection{Longitudinal Strain in Composite Beams}

The longitudinal strain on the bottom of a continuous composite beam is a significant index reflecting the degree of beam plasticity. Fig. 10 displays the longitudinal strain distribution on the bottom of continuous composite beam specimens at different loading stages. From a comparative analysis of Fig. 10, several conclusions can be obtained:

1) The opening location has a large effect on the plasticity of continuous composite beams. Taking TCB1 as an example, in the range of $0.75-1.00 P_{\mathrm{u}}$, the critical sections of TCB1 still have a certain degree of crosssectional bending plasticity (in the width and height directions) in the mid-span and mid-support, even though the shear failure ultimately occurs at the web opening, but this pattern is not obvious for specimens TCB2-TCB4.

2) As the opening location approaches the hogging moment region (TCB2-TCB4), a less obvious bending plasticity development was observed in the critical sections until shear failure occurred at the web opening of specimens TCB2-TCB4.

\subsection{Moments Redistribution}

Tab. 4 gives the ultimate bending moment values of the composite beam specimens obtained by different analytical methods (elastic analysis and nonlinear analysis) for beams with and without web openings. The amplitude modulation coefficient $\beta$ can be calculated using Eq. (3) as follows:

$\beta=\frac{M_{\mathrm{e}}-M^{\prime}}{M_{\mathrm{e}}}$

where $M_{\mathrm{e}}$ is the elastic moment calculated using the elastic method at the internal support, and $M^{\prime}$ is the ultimate bending moment obtained by nonlinear finite element analysis at the internal support.

Compared with the corresponding results in Tab. 4, both the existence of web openings and the opening location have particular effects on the moment redistribution for continuous composite beams.

More intuitively, the data in Tab. 4 can be illustrated in Fig. 11. Obviously, compared with composite beams without web openings, there are amplitude modulations at two moments in beams with web openings: one is the socalled "moment amplitude modulation" caused by web openings in the elastic stage; the other is the moment modulation caused by the plasticity of the composite beams after they enter the elastic-plastic stage.

Table 4 Redistribution of moment in composite beam specimens

\begin{tabular}{|c|c|c|c|c|c|c|c|c|c|c|c|}
\hline \multirow{3}{*}{ No. } & \multirow{3}{*}{$\begin{array}{c}\text { Ultimate } \\
\text { load }\end{array}$} & \multicolumn{2}{|c|}{$\begin{array}{l}\text { Elastic moment of ultimate } \\
\text { load (Without openings) }\end{array}$} & \multicolumn{2}{|c|}{$\begin{array}{l}\text { Elastic moment of ultimate } \\
\text { load (With openings) }\end{array}$} & \multicolumn{2}{|c|}{ Ultimate bending moment } & \multirow{3}{*}{$\begin{array}{l}\begin{array}{l}\text { Opening } \\
\text { location }\end{array} \\
b_{1} / \mathrm{mm}\end{array}$} & \multicolumn{3}{|c|}{$\beta$} \\
\hline & & \multirow{2}{*}{$\begin{array}{l}\text { Mid-span } \\
/ \text { kNm }\end{array}$} & \multirow{2}{*}{$\begin{array}{c}\text { Internal support } \\
/ \mathrm{kNm}\end{array}$} & \multirow{2}{*}{$\begin{array}{l}\text { Mid-span } \\
\text { / kNm }\end{array}$} & \multirow{2}{*}{$\begin{array}{l}\text { Internal support } \\
\qquad / \mathrm{kNm}\end{array}$} & \multirow{2}{*}{$\begin{array}{l}\text { Mid-span } \\
\text { / kNm }\end{array}$} & \multirow{2}{*}{$\begin{array}{l}\text { Internal support } \\
\qquad / \mathrm{kNm}\end{array}$} & & \multicolumn{2}{|c|}{ Caused by } & \multirow[b]{2}{*}{ In total } \\
\hline & & & & & & & & & Opening & Plasticity & \\
\hline TCB1 & 354 & & & 169.78 & & & & 55 & 0.04 & 0.37 & 0.41 \\
\hline TCB2 & 27 & & & 138.56 & & & & 1650 & 0.10 & 0.35 & 0.45 \\
\hline TCB3 & 274 & 128.23 & 154.54 & 136.45 & 138.10 & 170.98 & 48.50 & 1950 & 0.11 & 0.65 & 0.76 \\
\hline TCB4 & 220 & 103.13 & 123.75 & 110.35 & 109.29 & 136.88 & 51.95 & 2350 & 0.12 & 0.52 & 0.64 \\
\hline
\end{tabular}

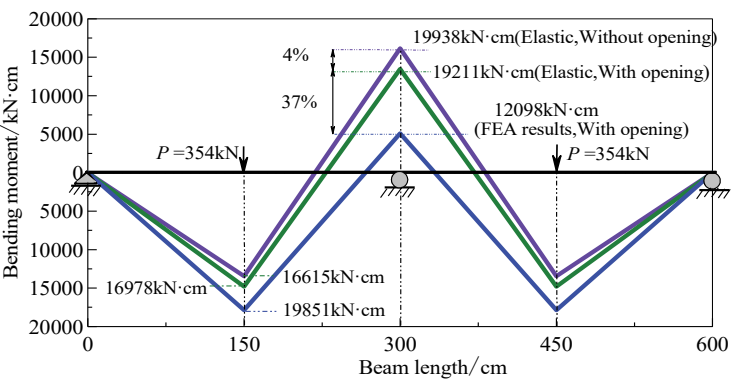

(a) TCB1

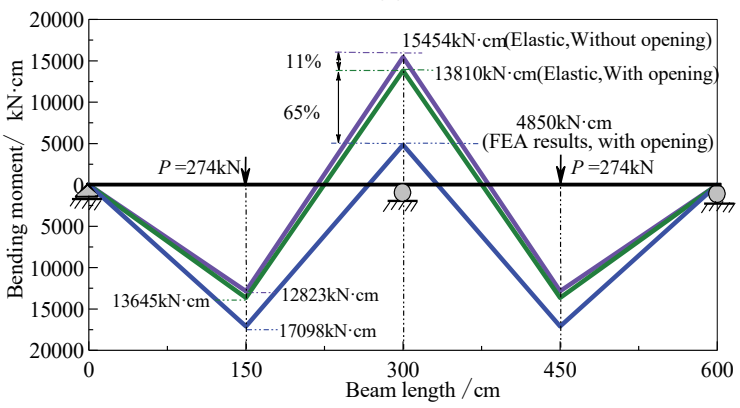

(c) TCB3

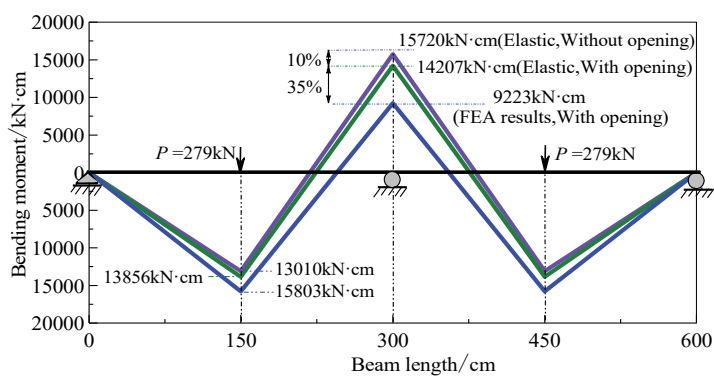

(b) TCB2

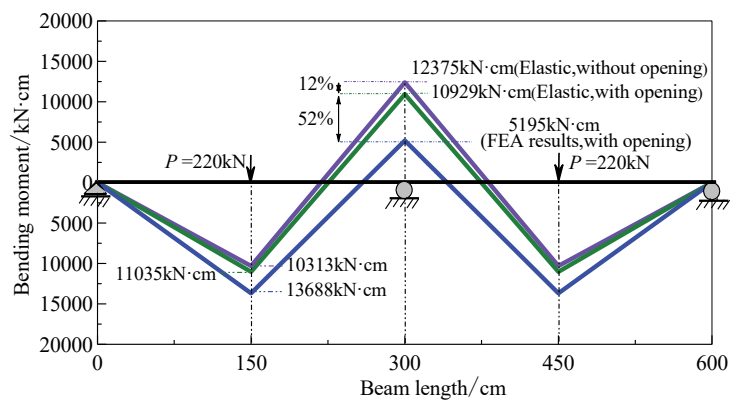

(d) TCB4

Figure 11 Two moment modulation of composite beams caused by opening and plasticity

\section{CONCLUSIONS}

1) Web opening not only reduces the stiffness and strength of continuous composite beams but also affects their bearing capacity, deformation capacity, plastic development and the redistribution of internal forces.

2) The web opening location affects the ultimate loadcarrying capacity and deformability of continuous 
composite beams. The strength and deformation capacity of specimens TCB1-TCB4 decrease gradually as the opening location moves towards the internal support (hogging bending moment region).

3) The vertical shear force redistribution at the web opening indicates the steel beams ultimately bear most of the shear force, while the concrete slabs bear a small part of the shear force on the cross-section. On the other hand, the vertical shear force redistribution also reflects that the vertical shear force at the web opening region may play a controlling role in the load-carrying capacity in beam design.

4) The longitudinal strain on the bottom of a continuous composite beam is a significant index that reflects the degree of beam plasticity. Although all the composite beams with web openings in this simulation ultimately suffer from shear failure at the opening, for TCB1, a certain degree of the plasticity is allowed to develop in the midspan and intermediate support, and the trend of bending moment plastic hinges is obvious.

5) Web openings and their locations significantly influence the moment modulation of continuous composite beams. Compared to beams without web openings, specimens with web openings have amplitude modulations at two moments caused by web opening and plastic development; the second moment modulation is larger than the first.

In conclusion, this paper presents the optimum opening position of continuous composite beams with a rectangular web opening. Further studies will be needed for beams with different shapes and sizes of web openings.

\section{Acknowledgments}

The authors gratefully acknowledge the Science and Technology Project of Henan Province (Grant No: 182102310911). In addition, the authors would like to thank the anonymous referees for their constructive comments and suggestions.

\section{REFERENCES}

[1] Clawson, W. C. \& Darwin, D. (1982). Strength of composite beams at web openings. Journal of the Structural Division, American society of civil engineers, 108(3), 623-641. https://doi.org/10.1016/0022-1694(82)90165-2

[2] Redwood, R. \& Cho, S. H. (1993). Design of steel and composite beams with web openings. Journal of Constructional Steel Research, 25(1-2), 23-41. https://doi.org/10.1016/0143-974X(93)90050-3

[3] Chung, K. F. \& Lawson, R. M. (2001). Simplified design of composite beams with large web openings to Eurocode 4. Journal of Constructional Steel Research, 57(2), 135-164. https://doi.org/10.1016/S0143-974X(00)00011-0

[4] Donahey, R. C. \& Darwin, D. (1982). Web openings in composite beams with ribbed slabs. Journal of Constructional Steel Research, 114(3), 518-534. https://doi.org/10.1061/(ASCE)0733-9445(1988)114:3(518)

[5] Cho, S. H. \& Redwood, R. G. (1992). Slab behavior in composite beams at openings. I: Analysis. Journal of Constructional Steel Research, 118(9), 2287-2303. https://doi.org/10.1061/(ASCE)0733-9445(1992)118:9(2287)

[6] Ellobody, E. \& Young, B. (2015). Behaviour and design of composite beams with stiffened and unstiffened web opening. Advances in Structural Engineering, 18(6), 893-918. https://doi.org/10.1260/1369-4332.18.6.893
[7] Lawson, R. M., Lim, J. B. P., \& Popo-Ola, S. O. (2013). Pullout forces in shear connectors in composite beams with large web openings. Journal of Constructional Steel Research, 87, 48-59. https://doi.org/10.1016/j.jcsr.2013.03.025

[8] Darwin, D. (2000). Design of composite beams with web openings. Progress in Structural Engineering and Materials, 2(2), 157-163. https://doi.org/10.1002/1528-2716(200004/06)2:2<157::AIDPSE23>3.0.CO;2-A

[9] Liao, W., Li, L., Liu, D., Dai, B., \& Wang, C. (2018). Nonlinear FEM analysis on composite beams with web opening under negative bending moment. Tehnicki Vjesnik, 25(5), 1546-1552. https://doi.org/10.17559/TV-20180626222438

[10] Yu, N. T., Kim, B., Yuan, W. B., Li, L. Y., \& Yu, F. (2019). An analytical solution of distortional buckling resistance of cold-formed steel channel-section beams with web openings. Thin-Walled Structures, 135, 446-452. https://doi.org/10.1016/j.tws.2018.11.012

[11] Lawson, R. M. \& Basta, A. (2019). Deflection of C section beams with circular web openings. Thin-Walled Structures, 134, 277-290. https://doi.org/10.1016/j.tws.2018.10.010

[12] Weil, T. \& Schnell J. (2007). Ein Bemessungsmodell für durchlaufende Verbundträger mit großen Stegöffnungen. Stahlbau, 76(7), 495-502. https://doi.org/10.1002/stab.200710053

[13] Li, L., Liao, W., Wang, J., \& Zhou, D. (2015). Behavior of continuous steel-concrete composite beams with web openings. International Journal of Steel Structures, 15(4), 989-997. https://doi.org/10.1007/s13296-015-1218-2

[14] Code for Design of ConcreteStructures.,Ministry of Construction of the People's Republicof China, China Planning Press, Beijing, China.

[15] Hognestad, E., Hanson, N. W., \& Rüsh H. (1951). Study of combined bending and axial load in reinforced concrete members. University of Illinois Bulletin, 49(22), 123-128,

[16] Ollgaard, J. G., Slutter, R. G., \& Fisher, J. W. (1971). Shear strength of stud connectors in lightweight and normal weight concrete. AISC Engineering Journal, 71-10.

[17] Fritz Laboratory Reports (2010). Retrieved from https://preserve.lehigh.edu/engr-civilenvironmental-fritz-lab-reports/2010

\section{Contact information:}

Longqi LI

Department of Architectural and Civil Engineering,

Weifang University, Weifang, China

E-mail: Ilq_xcu@163.com

\section{Wenyuan LIAO}

(Corresponding author)

College of Civil Engineering,

Southwest Forestry University,

No. 300, Bailong Temple, Panlong District,

650224 Kunming, Yunnan Province, China

E-mail: Iwy065@126.com

\section{Bingyong HUO}

Department of Civil Engineering,

Xuchang University, Xuchang, China

E-mail: 2264810170@qq.com 